\title{
Nutritive value of silage made of whole barley crop harvested at various stages of maturity
}

\author{
F. Borowiec ${ }^{1}$, K. Furgal', J. Kamiński' and T. Zając ${ }^{2}$ \\ 'Department of Animal Nutrition, 'Department of Plant Science, \\ Agricultural University of Kraków \\ Al. Mickiewicza 24/28, 30-059, Kraków, Poland
}

(Received 8 July 1997; accepted 14 January 1998)

\begin{abstract}
The chemical composition of silage from whole crop barley (Hordeum vulgare L.) harvested at head emergence, milk or dough stage of maturity was estimated and palatability and digestibility trials on sheep were conducted.

Crude protein and ADF content in DM decreased with advancing maturity from about 104 to 84 and 350 to $306 \mathrm{~g} / \mathrm{kg}$, whereas DM, ADL and $\mathrm{N}$-free extractives increased at the same time from 222 to $317 ; 27$ to 39.6 , and 439 to $522 \mathrm{~g} / \mathrm{kg}$, respectively. Palatability and voluntary intake of silage produced from barley harvested at milk and dough stages of maturity were higher.

The proportion of lactic acid to total acids was similar in all silages $(0.85)$, the percent of $\mathrm{NH}_{3}-\mathrm{N}$ in total $\mathrm{N}$ decreased with advancing maturity from 13.3 to 10.0. Voluntary silage DM intake increased with maturity of barley, but digestibility of crude fibre, NDF, ADF, ether extract and N-free extractives decreased. Silage contained (per kg of DM): $103.8,93.9,83.7 \mathrm{~g}$ of crude protein; $63.8,57.7$, $51.4 \mathrm{~g}$ PDIN; 70.9, 67.6, 66.3 g PDIE and 0.68, 0.67, 0.70 UFL at head emergence, milk and dough stages of maturity, respectively. Harvesting of whole crop barley at milk or dough stage of maturity is recommended for silage making.
\end{abstract}

KEY WORDS: whole crop silage, barley, sheep, palatability, voluntary feed intake, nutritive value

\section{INTRODUCTION}

Intensive animal production requires both the right quantity and high nutritional value of feeds. This is particularly valid for forages, which constitute the basic feed for ruminants (Borowiec et al., 1988; Jarrige, 1989; Kraszewski et al., 1995). Among the forages produced on arable lands, more attention has been paid to whole crop 
cereal plants and their mixtures with leguminous plants intended for direct feeding as green forage or for ensiling (Mikołajczak, 1989; Bergen et al., 1991; Huhtanen, 1991; McCartney and Vaage, 1993; Ostrowski and Daczewska, 1993; Borowiec et al., 1997; Khorasani et al., 1997).

The stage of growth of the whole crop cereal plant used for ensiling has a major influence on the quality and nutritional value of silage (Brundage et al., 1979; Acosta et al., 1991; Bergen at al., 1991). A delay in the harvest date has increased dry matter and water-soluble carbohydrate contents in the herbage, which can positively effect the fermentation processes in the silo, and then it can increase dry matter intake. On the other hand, during growth, cell walls lignify and this can decrease in vivo digestibility (Acosta et al., 1991; Urbański and Brzóska, 1996).

The objective of this study was to determine the effect of the stage of maturity of whole spring barley crop on silage quality, nutrient digestibility, $\mathrm{N}$ balance and voluntary feed intake by growing sheep.

\section{MATERIAL AND METHODS}

\section{Silage crop}

The crop for ensiling was green forage of spring barley Ars (Hordeum vulgare L.), grown on a steppe/forest degraded black-soil of the first class quality. Barley was sown at a rate of 300 seeds $/ \mathrm{m}^{2}$, which was equal to $126 \mathrm{~kg}$ of seeds per 1 ha. Before sowing, mineral fertilization was applied in the following rate: $30 \mathrm{~kg} \mathrm{~N} / \mathrm{ha}, 60 \mathrm{~kg}$ $\mathrm{P}_{2} \mathrm{O}_{5} / \mathrm{ha}$ and $80 \mathrm{~kg} \mathrm{~K} 2 \mathrm{O} / \mathrm{ha}$. The total rainfall during the vegetation period was 385 $\mathrm{mm}$, and the average temperature $14.5^{\circ} \mathrm{C}$. After the stage of head emergence, the prevailing hot and humid weather conditions were favourable for grain formation.

Green barley was harvested at three stages of maturity: head emergence, milk or dough grain ripeness. The period from the sowing to harvest was 67,82 and 96 days, respectively. After being cut into $1-2 \mathrm{~cm}$ long particle size, the barley was ensiled in 751 plastic containers, $0.8 \mathrm{~kg}$ of fresh matter per $1 \mathrm{dm}^{3}$. Whole barley crops of each stage of growth were ensiled in 8 containers for the in vivo trials. Samples of the green herbages or silages, representing three layers in containers, were collected for chemical analysis.

\section{Trials with animals}

Palatability. The palatability of silages was tested on 6 rams of Longhair Polish sheep, 7 months old, $45 \mathrm{~kg}$ average body weight, kept in individual cages. Three silages offered ad libitum were given simultaneously to each ram, in separate plastic buckets. The initial period of adaptation to the silages was 21 days, followed by 
7 days of detailed observations. During the test, the animals received silages twice a day in portions of $2 \mathrm{~kg}$ of each silage. If consumed entirely the next $2 \mathrm{~kg}$ portion was given. Daily intake of each silage was measured.

Voluntary feed intake. In order to establish maximum silage consumption, another test was carried out on similar 12 rams divided into 3 groups. Each group of animals was fed ad libitum for 21 days with silage made of barley harvested at different stages of growth and voluntary feed intake was measured.

Digestibility and $\mathrm{N}$-balance. An experiment was carried out on 12 rams divided into 3 groups. Each group of rams received a different type of silage ad libitum as the only forage in the ration, with an addition of $20 \mathrm{~g} /$ day/animal of a mineral mixture. The preliminary period of the trial lasted 21 days, and the faeces and urine were collected for next 7 days. Samples of silage and faeces were kept at $-18^{\circ} \mathrm{C}$ until analysed. Urine was preserved with hydrochloric acid.

\section{Chemical analyses and calculations}

The chemical composition of fresh barley, silages and refusals was analysed using standard methods (AOAC, 1990), the content of water-soluble carbohydrate (WSC) was determined according to the Deriaz method (1961), and buffer capacity of herbage according to Playne and McDonald (1966). The $\mathrm{pH}$ values in silages was determined potentiometrically, the content of acids and alcohol using a GLC Varian Star $3400 \mathrm{CX}$ with FI detector, argon as the carrier gas, DB-FFAP column, $90-205^{\circ} \mathrm{C}$, sample injector temperature $200^{\circ} \mathrm{C}$ and detector temperature $240^{\circ} \mathrm{C}$. The content of $\mathrm{NH}_{3}-\mathrm{N}$ in silages was determined using the Conway method (1947) and the contents of NDF and ADF according to Goering and Van Soest (1970). The quality of silages was assessed using the Flieg-Zimmer scale (Podkówka, 1978).

The chemical composition of faeces was determined using standard AOAC methods (1990) after drying at $55^{\circ} \mathrm{C}$ for $24 \mathrm{~h}$, but nitrogen was determined in fresh material.

The nutritive value of silages was calculated according to the INRA system (Jarrige, 1989), using Winwar 1.21 computer software. The results were subjected to analysis of variance using the GLM procedure of SAS.

\section{RESULTS AND DISCUSSION}

An increase of dry matter content in whole crop barley with advancing maturity was accompanied by an increase in the contents of ether extract, $\mathrm{N}$-free extractives and water-soluble carbohydrates (\% DM) (Table 1). The crude protein content of barley harvested at the milk and dough stage of maturity was lower than that cut at the head emergence stage. As a result of these changes, the buffer capacity of the 
TABLE 1

Chemical composition of fresh whole barley crop, $\mathrm{g} / \mathrm{kg}^{-1}$

\begin{tabular}{lccc}
\hline & \multicolumn{3}{c}{ Barley grain ripeness stage } \\
\cline { 2 - 4 } Item & head emergence & milk & dough \\
\hline Dry matter & 245.0 & 291.0 & 333.4 \\
Buffer capacity mEq 100 g of dry matter $^{-1}$ & 24.4 & 17.9 & 14.5 \\
In dry matter: & & & \\
$\quad$ crude protein & 105.9 & 97.3 & 91.8 \\
ether extract & 21.6 & 25.1 & 25.5 \\
crude fibre & 254.2 & 230.9 & 233.6 \\
$\quad$ N-free extractives & 505.1 & 535.4 & 589.9 \\
water-soluble carbohydrates & 224.6 & 232.7 & 271.4 \\
\hline
\end{tabular}

forage cut at the milk and dough grain ripeness stages was reduced. Whole cereal crop of advanced maturity was more suitable for ensiling due to the changes in the chemical composition of plants, which is in line with the results of other authors (Acosta et al., 1991; Bergen et al., 1991; Podkówka and Potkański, 1993; Brundage et al., 1997).

TABLE 2

Chemical composition $\left(\mathrm{g} / \mathrm{kg}^{-1}\right)$ and quality of silages

Barley grain ripeness stage

\begin{tabular}{lrrr} 
Item & head emergence & milk & dough \\
\hline pH & 4.1 & 3.9 & 3.9 \\
Dry matter & 222.1 & 272.5 & 316.7 \\
In dry matter: & & & \\
$\quad$ crude protein & 103.8 & 93.9 & 83.7 \\
ether extract & 35.0 & 35.2 & 42.0 \\
crude fibre & 316.4 & 253.9 & 260.8 \\
NDF & 653.9 & 522.9 & 603.6 \\
ADF & 349.6 & 317.1 & 306.0 \\
ADL & 27.0 & 32.7 & 39.6 \\
N-free extractives & 438.7 & 500.3 & 522.0 \\
water-soluble carbohydrates & 116.6 & 124.4 & 114.9 \\
lactic acid (L) & 61.8 & 70.8 & 45.0 \\
acetic acid (A) & 10.0 & 9.9 & 6.4 \\
butyric acid & 1.2 & 2.3 & 0.9 \\
ethanol & 8.4 & 12.5 & 16.0 \\
Acid proportions: & & & \\
L : A & 6.1 & 7.1 & 7.0 \\
L : total acids & 0.85 & 0.85 & 0.86 \\
N-NH $\%$ of total N & 13.3 & 12.4 & 10.0 \\
Flieg-Zimmer score (points) & 80.0 & 80.0 & 80.0 \\
\hline
\end{tabular}


During the ensiling processes, about $50 \%$ of carbohydrates, particularly those that were water-soluble, was decomposed, whereas the content of crude fibre and fat in dry matter increased by $10-19$ and $30-40 \%$, respectively (Tables 1 and 2). The greatest decrease in carbohydrate content was observed in the silage produced from barley harvested at the dough stage of maturity. This silage also had the highest content of ethanol. The effect of barley grain ripeness stage on silage chemical composition was similar to that observed by other authors (Acosta et al., 1991; Bergen et al., 1991; Brundage et al., 1997; Khorasani et al., 1997).

The greatest content of lactic acid was found, similarly as in the experiment of Bergen et al. (1991), in the silage made of barley cut at the milk stage, and the lowest at the dough stage. The concentration of butyric acid was lowest in the dough stage silage and the highest at the milk stage. The proportion of lactic to acetic acid was similar in the silages made of barley at milk and dough stage and higher than in the head emergence silage.

No differences among treatments were found in the proportion of lactic to total acids and in the quality of all silages according to the Flieg-Zimmer scale, reaching about 80 points. These silages were classified as having good quality, irrespective of the stage of growth. In this context, it is not clear why the content of $\mathrm{NH}_{3}-\mathrm{N}$ in total $\mathrm{N}$ of each silage was, like in the experiment of Bergen et al. (1991), rather high exceeding $10 \%$ of total $\mathrm{N}$. This could point to a certain level of proteolysis in the silo, particularly in silages of lower dry matter content.

The silage intake by sheep at free-access to feed is presented in Table 3. Rams which had free access to three different silages showed a significantly higher preference for silages made of barley harvested at the later stages of maturity. The highest dry matter intake was found for the dough stage silage $(\mathrm{P}<0.01)$, being about double the intake of the head emergence silage. Dry matter intake of silages made of

TABLE 3

The effect of barley grain ripeness stage on the free-access silage consumption by sheep

\begin{tabular}{|c|c|c|c|c|c|}
\hline \multirow[b]{2}{*}{ Item } & \multicolumn{5}{|c|}{ Barley grain ripeness stage } \\
\hline & & head emergence & milk & dough & total \\
\hline \multirow[t]{2}{*}{ Silage } & $\mathrm{kg}$ & $1.18^{\mathrm{Aad}}$ & $1.48^{\mathrm{b}}$ & $1.70^{\mathrm{B}}$ & 4.36 \\
\hline & $\%$ & 27.1 & 33.9 & 39.0 & 100 \\
\hline \multirow[t]{2}{*}{ Dry matter } & $\mathrm{g}$ & $262.5^{\wedge a}$ & $403.3^{b}$ & $538.4^{\mathrm{Bc}}$ & 1204.2 \\
\hline & $\%$ & 21.8 & 33.5 & 44.7 & 100 \\
\hline \multirow[t]{2}{*}{ Crude protein } & $\mathrm{g}$ & $27.3^{\mathrm{Aa}}$ & $33.9^{\mathrm{b}}$ & $45.1^{\mathrm{Bc}}$ & 106.3 \\
\hline & $\%$ & 25.7 & 31.9 & 42.4 & 100 \\
\hline \multirow[t]{2}{*}{ Net energy* } & MJ & $1.54^{\mathrm{Aa}}$ & $2.43^{\mathrm{b}}$ & $3.02^{\mathrm{Bb}}$ & 6.99 \\
\hline & $\%$ & 22.0 & 34.8 & 43.2 & 100 \\
\hline
\end{tabular}

* calculated from starch units according to Kamiński et al. (1995)

A, B $-\mathrm{P}<0.01 ; \mathrm{a}, \mathrm{b}, \mathrm{c}-\mathrm{P}<0.05$ 
barley cut at the milk and dough stages of maturity was 33.5 and $44.7 \%$ of total DM intake, respectively, while the head emergence stage silage accounted for only $21.8 \%$ of total DM consumption. The same tendency was found for crude protein and net energy intake.

Dry mater intake increased with advancing maturity of barley $(\mathrm{P}<0.05)$. Compared with the head emergence silage, the intakes of dry matter and net energy from the milk and dough stage silages were higher by about 23 and $30 \%$ for DM, and 28 and $25 \%$ for net energy, respectively. The same tendency was shown by Furgał et al. (1989), who observed higher DM intake by sheep fed silages of increased DM content. Also studies on dairy cows carried out by Acosta et al. (1991) using barley silages and by Urbański and Brzóska (1996) using cereal/leguminous mixture silages, have demonstrated that cutting crops at a later stage of growth had a positive influence on dry matter and energy intake. On the other hand, the intake of crude protein was the highest for the milk stage silage $(\mathrm{P}<0.05$ ), with no differences between other two silages (Table 4).

TABLE 4

The effect of barley grain ripeness stage on the voluntary intake of silages by sheep

\begin{tabular}{|c|c|c|c|}
\hline \multirow[b]{2}{*}{ Item } & \multicolumn{3}{|c|}{ Barley grain ripeness stage } \\
\hline & head emergence & milk & dough \\
\hline \multicolumn{4}{|l|}{ Dry matter: } \\
\hline $\mathrm{g} /$ day $^{-1}$ & $879.9^{\mathrm{a}}$ & $1084.5^{\mathrm{h}}$ & $1146.4^{b}$ \\
\hline $\mathrm{g} / \mathrm{kg} \mathrm{W}^{0.75}$ & $49.6^{\mathrm{a}}$ & $61.6^{\mathrm{b}}$ & $63.5^{\mathrm{b}}$ \\
\hline Crude protein, g/day ${ }^{-1}$ & $91.2^{\mathrm{a}}$ & $101.8^{b}$ & $95.9^{\mathrm{a}}$ \\
\hline Net energy, MJ/day ${ }^{-1}$ & $5.15^{a}$ & $6.57^{\mathrm{b}}$ & $6.45^{\mathrm{b}}$ \\
\hline \multicolumn{4}{|c|}{ Covering the requirements $* \%$} \\
\hline dry mater & 71.7 & 88.5 & 93.6 \\
\hline crude protein & 49.3 & 55.0 & 51.8 \\
\hline net energy & 72.5 & 92.5 & 90.8 \\
\hline
\end{tabular}

Silages consumed ad libitum as the only forage covered from $72.5 \%$ of the net energy requirements when the head emergence stage silage was fed, to 92.5 and $90.8 \%$ in the case of the milk and dough stage silages, respectively. Only about $50 \%$ of the protein requirement can be covered by any of the silages, irrespective of the stage of barley growth.

No significant differences among treatments were observed in dry matter and organic matter digestibility (Table 5). A significant decrease in digestibility of crude fibre, NDF and ADF $(\mathrm{P}<0.01)$ with increasing maturity of barley was found, while 
crude protein $(\mathrm{P}<0.01)$ and ether extract $(\mathrm{P}<0.05)$ digestibility decreased dramatically when the dough stage silage was fed. $\mathrm{N}$-free extractives digestibility of silages of a later stage of maturity was higher as they contained more easily digested carbohydrates. These results are consistent with those obtained by other authors (Acosta et al., 1991; McCartney and Vaage, 1993; Urbański and Brzóska, 1996), who demonstrated the decrease in digestibility of crude protein and fibre of whole crop silage when the cereal plants were cut at later growth stages. The lignification of cell walls which takes place as growth progresses, adversely affects the digestibility of both non-soluble (cell wall) and soluble components of the plant.

The animals fed the dough stage silage retained significantly more nitrogen $(\mathrm{P}<0.05)$ than animals from the remaining groups, particularly when the $\mathrm{N}$ balance was expressed as a $\%$ of $\mathrm{N}$ intake or $\mathrm{N}$ digested (Table 5). It can be assumed that a greater supply of readily available energy (mainly as starch) in dough stage silage can be responsible for more effective microbial synthesis in the rumen and, as a result, for increased retention of nitrogen by animals.

TABLE 5

The effect of barley grain ripeness stage on nutrient digestibility and nitrogen balance in sheep

\begin{tabular}{lccc}
\hline & \multicolumn{3}{c}{ Barley grain ripeness stage } \\
\cline { 2 - 4 } Item & head emergence & milk & dough \\
\hline Digestibility, \% & & & \\
dry matter & 69.0 & 66.3 & 66.6 \\
organic matter & 74.3 & 75.2 & 71.6 \\
crude protein & $65.9^{\mathrm{A}}$ & $68.4^{\mathrm{A}}$ & $58.8^{\mathrm{B}}$ \\
crude fibre & $76.4^{\mathrm{A}}$ & $71.0^{\mathrm{A}}$ & $58.5^{\mathrm{B}}$ \\
$\mathrm{NDF}$ & $72.5^{\mathrm{Aa}}$ & $60.0^{\mathrm{b}}$ & $53.0^{\mathrm{B}}$ \\
ADF & $65.5^{\mathrm{A}}$ & $62.4^{\mathrm{Ab}}$ & $44.3^{\mathrm{Bb}}$ \\
ether extract & $80.6^{\mathrm{a}}$ & $80.2^{\mathrm{a}}$ & $71.0^{\mathrm{b}}$ \\
$\mathrm{N}$-free extractives & $72.5^{\mathrm{Aa}}$ & $78.1^{\mathrm{b}}$ & $80.2^{\mathrm{Bb}}$ \\
& & & \\
$\mathrm{N}-$-retained: g/day & & $1.8^{\mathrm{a}}$ & $3.0^{\mathrm{b}}$ \\
$\%$ of $\mathrm{N}-$-intake & $2.0^{\mathrm{a}}$ & $13.3^{\mathrm{A}}$ & $20.6^{\mathrm{B}}$ \\
$\%$ of $\mathrm{N}$ - digested & $11.5^{\mathrm{A}}$ & $20.4^{\mathrm{A}}$ & $32.1^{\mathrm{B}}$ \\
\hline
\end{tabular}

$\mathrm{a}, \mathrm{b}-\mathrm{P}<0.05 ; \mathrm{A}, \mathrm{B}-\mathrm{P}<0.01$

There were no differences between silages in net energy value regardless of the system of calculation used (Table 6). Although the content of energy compounds in silages increases with advancing maturity (Table 2), lower digestibility of these nutrients in the milk and dough stage silages (Table 5) seems to be responsible for a lack of differences in energy value between silages. On the other hand, PDIN and PDIE ( $\mathrm{g} / \mathrm{kg}$ of DM) values were decreased in the later stage silages, mainly as a result of their lower crude protein content. 
TABLE 6

The effect of barley grain ripeness stage on the nutritive value of silages calculated according to the INRA 1988 system

\begin{tabular}{lccc}
\hline & \multicolumn{3}{c}{ Barley grain ripeness stage } \\
\cline { 2 - 4 } Item & head emergence & milk & dough \\
\hline Dry matter, g/kg & 222.5 & 272.0 & 316.7 \\
In 1 kg of dry matter: & & & \\
crude protein, g & 103.8 & 93.9 & 83.7 \\
PDIN* g & 63.8 & 57.7 & 51.4 \\
PDIE* g & 70.9 & 67.6 & 66.3 \\
UFL* & 0.68 & 0.67 & 0.70 \\
net energy** & 5.86 & 6.09 & 5.61 \\
\hline
\end{tabular}

* The French INRA 1988 units:

PDIN - protein truly digestible in the small intestine, when energy is not limiting

PDIE - protein truly digestible in the small intestine, when degraded $\mathrm{N}$ is not limiting

UFL - feed unit for milk production

** calculated from starch units according to Kamiński et al. (1995)

In summary, it can be assumed that whole barley crop is a good material for silage production, regardless of the stage of growth. Consequently, the use of this type of silage in practice should be encouraged as an important source of energy for ruminants.

\section{REFERENCES}

Acosta Y. M., Stallings C.C., Polan C.E., Miller C.N., 1991: Evaluation of barley silage harvested at boot and soft dough stages. J. Dairy Sci. 74, 167-176

AOAC, 1990. Official Methods of Analysis of the Association of Official Analytical Chemists. 15th Edition, Arlington, Virginia, USA

Bergen W.G., Byrem T.M, Grant A.L., 1991. Ensiling characteristics of whole-crop small grains harvested at milk and dough stages. J. Anim. Sci. 69, 1766-1774

Borowiec F., Furgał K., Kamiński J., Kowalski Z., Pająk E., 1988. The effect of the ensiling method of mountain pasture sward on the quality and nutritional value of silages (in Polish). Zesz. probl. Post. Nauk rol. No 361, 147-152

Borowiec F., Pisulewska E., Furgal K., 1996. Mixed cereal-vetch forage as a silage crop in sustainable farming. 4th Congress of European Society for Agronomy, The Netherlands. Vol. II, Theme 2, Agroforestry Session Division

Borowiec F., Pisulewska E., Furgał K., Zając T., 1997. Green triticale as a raw material for ensiling (in Polish). Zesz. Nauk. AR Szczecin, 175, Roln. 65, 27-34

Brundage A. L., Taylor R.L., Burton V.L., 1979. Relative yields and nutritive values of barley, oats and peas harvested at four succesive dates for forage. J. Dairy Sci. 62, 741-745

Conway E.J., 1947. Microdiffusions Analysis and Volumetric Error. Crosby Locwood, London

Deriaz R.E., 1961. The routine analysis of carbohydrates and lignin in herbage. J. Sci. Food Agric. $12,152-160$ 
Furgał K., Kamiński J., Borowiec F., 1989. The effect of the degree of partial drying of green mass from mountain pastures on the quality and nutritive value of silage (in Polish). Zesz. Nauk. AR Kraków 229, 83-96

Goering H.K., Van Soest P.J., 1970. Forage Fiber Analysis, US Dept. Agric., Washington DC, Handbook 379, 1-20

Huhtanen P., 1991. Effects of yeast culture supplement on digestion of nutrients and rumen fermentation in cattle fed on grass silage barley diet. J. Agric. Sci. Finland 63, 443-451

Jarrige R., 1989. Ruminant Nutrition. INRA, John Libbey, Eurotext, London-Paris

Kamiński J., Borowiec F., Furgal K., Barteczko J., Kowalski Z., Pyś J., Siuta A., Pisulewski P., Lehman B., 1995. Animal Feeds and Feeding - Exercises (in Polish). Materials for Students of Agricultural University, Kraków

Khorasani G.R., Jedel P.E., Helm J.H., Kennelly J.J., 1997. Influence of stage of maturity on yield components and chemical composition of cereal grain silages. Can. J. Anim. Sci. 77, 259-267

Kraszewski J., Wawrzyńczak S., Bielak F., Wawrzyński M., Kozłowski J., 1995. Suitability of legume-cereal silage for fattening of young bulls (in Polish). Rocz. Nauk Zoot. 22, 221-230

McCartney D.H., Vaage A.S., 1993. Comparative yield and feeding value of barley, oat and triticale silages. Can. J. Anim. Sci. 71, 91-96

Mikolajczak J., 1989. The nutritive value of whole cereal crop silages made with different additives (in Polish). Proceedings of 21 st Session of Committee of Zootechnical Sciences, Polish Academy of Sciences, Poznań (Poland)

Ostrowski R., Daczewska M., 1993. The yield of cereal-pulse mixtures grown in the Wielkopolska region, and nutritive value of silages and dehydrated forages for ruminants (in Polish). Rocz. Nauk Zoot. 20, (2), 157-169

Playne M. J., Mc Donald P., 1966. The buffering constituents of herbage and of silage. J. Sci. Food Agric. 17, 264-268

Podkówka W., 1978. Modern Methods of Ensiling (in Polish). PWRiL, Warszawa

Podkówka W., Potkański A., 1993. The effect of chemical and physical characteristics on suitability of herbage for ensiling (in Polish). Post. Nauk rol. 40, 29-42

Polish Standard BN-74 9162-01

Ryś R., 1993. Feeding Standards for Cattle and Sheep. Traditional System (in Polish). Institute of Animal Production, Kraków (Poland)

Urbański A., Brzóska F., 1996. Legume-cereal forage mixtures for silage. 1. Effect of pea variety, maturity and sowing density of mixture on dry matter yield and silage chemical composition. J. Anim. Feed Sci. 5, 107-116

Urbański A., Brzóska F., 1996. Legume-cereal forage mixtures for silage. 2. Nutritive value of silage for dairy cows. J. Anim. Feed Sci. 5, 117-126

\section{STRESZCZENIE}

\section{Wartość pokarmowa kiszonek z całych roślin jęczmienia zbieranego $\mathrm{w}$ trzech stadiach wegetacji}

Oznaczono skład chemiczny kiszonek przygotowanych z calych roślin jęczmienia jarego Ars (Hordeum vulgare L.) zbieranego w trzech stadiach rozwoju: kłoszenia, mlecznej i woskowej dojrzałości ziarna, a także strawność. bilans $\mathrm{N}$ oraz preferencje spożycia i ilość pobieranych kiszonek 
przy podawaniu ich do woli. Zawartość białka ogólnego i ADF w suchej masie kiszonek zmniejszała się w miarę dojrzałości roślin, z których przygotowano kiszonki, z 104 do 84 i 350 do $306 \mathrm{~g} / \mathrm{kg}$, odpowiednio, natomiast zawartość suchej masy, ADL i związków bezazotowych wyciągowych zwiększała się z 222 do $317 ; 27$ do 39,6, i 439 do 522 g/kg, odpowiednio.

Stosunek stężenia kwasu mlekowego do sumy kwasów był podobny we wszystkich kiszonkach i wynosił 0,85 , udział $\mathrm{NH}_{3}-\mathrm{N}$ w $\mathrm{N}$ ogólnym obniżał się w miarę postępu wegetacji roślin z 13,3 do $10,0 \%$.

Dowolne pobranie suchej masy przy skarmianiu kiszonek jako jedynej paszy, a także preferencja pobierania kiszonek przy oferowaniu zwierzątom wszystkich kiszonek do wyboru, zwiększały się w miarę postępującej dojrzałości jęczmienia, obniżała się natomiast strawność włókna surowego, NDF, ADF, ekstraktu eterowego i związków bezazotowych wyciągowych. Wartość energetyczna wszystkich kiszonek była podobna i wynosiła od 0,67 do 0,70 JPM. 